\title{
Physiological and behavioral responses of Nellore steers to artificial shading in an intensive production system
}

\section{Respostas fisiológicas e comportamentais de bovinos Nelore em sistema intensivo de produção com sombreamento artificial}

\author{
Diogo Alves da Costa Ferro ${ }^{1 *}$; Emmanuel Arnhold ${ }^{2}$; Claudia Peixoto Bueno ${ }^{1}$; \\ Eliane Sayuri Miyagi²; Rafael Alves da Costa Ferro'; \\ Aracele Pinheiro Pales dos Santos ${ }^{1}$; Klayto José Gonçalves dos Santos ${ }^{1}$; \\ Bruna Paula Alves da Silva ${ }^{3}$
}

\begin{abstract}
The influence of artificial shading on environmental variables and on behavioral responses of Nellore steers in an intensive production system was evaluated in this study. The experiment was conducted in the experimental feedlot of the Department of Animal Science at Universidade Estadual de Goiás, from July to October 2014. Forty-eight male Nellore cattle with an average initial weight of $310 \mathrm{~kg}$ were kept in double $24-\mathrm{m}^{2}$ stalls, in a total of 24 stalls. Of these, six were in the open air; six were covered with black shade netting of 30\% light interception; six with black shade netting $50 \%$; and six with black shade netting $80 \%$, providing $6 \mathrm{~m}^{2}$ of shade per stall. Temperature-humidity index (THI) and respiratory frequency $(\mathrm{RF})$ were assessed twice weekly and behavior was evaluated fortnightly during $12 \mathrm{~h}$, between 06:00 h and $18.00 \mathrm{~h}$. Feeding behavior, rumination, rest, and social activities such as body care and playful and abnormal activities were observed. A significant increase was found in THI and RF as the shading levels decreased, while a significant difference was recorded in rest and in other activities, water intake, and play behavior. Rest time and playful behavior increased significantly, and other activities and water intake decreased with the increase in shading levels. Shading does not change the time spent on feeding behaviors and rumination, or the frequencies of urination, defecation, cleaning other animals, self-cleaning, and social and abnormal types of behavior. The use of black shade netting of $80 \%$ light interception provides greater comfort to animals, promoting welfare and quality of life to them.
\end{abstract}

Key words: Ambience. Behavior. Performance. Welfare.

\section{Resumo}

Objetivou-se avaliar a influência dos níveis de sombreamento artificial nas variáveis ambientais e nas respostas comportamentais de machos bovinos nelore em sistema intensivo de produção. $\mathrm{O}$ experimento foi realizado no confinamento experimental do curso de Zootecnia da Universidade Estadual de Goiás, no período de julho a outubro de 2014. Utilizaram-se 48 bovinos machos Nelore, com peso médio inicial de $310 \mathrm{~kg}$, mantidos em baias duplas de $24 \mathrm{~m}^{2}$, sendo utilizados 24 baias, destas, seis a céu

\footnotetext{
${ }^{1}$ Profs. Drs. Titulares, Curso de Zootecnia, Universidade Estadual de Goiás, UEG, São Luís de Montes Belos, GO, Brasil. E-mail: diogo.ferro@ueg.br; vetcpb@gmail.com; rafael.ferro@ueg.br; aracele.pales@ueg.br; klayto.santos@ueg.br

2 Profs. Drs. Titulares, Escola de Veterinária e Zootecnia, UFG, Goiânia, GO, Brasil. E-mail: emmanuelarnhold@yahoo.com.br; eliane.miyagi@gmail.com

${ }^{3}$ Prof $^{a}$ M.e, Curso de Zootecnia, UEG, São Luís de Montes Belos, GO, Brasil. E-mail: bruna.silva@ueg.br

* Author for correspondence
} 
aberto, seis com sombrite preto com malha $30 \%$, seis com malha $50 \%$ e seis com malha $80 \%$, cobrindo seis $\mathrm{m}^{2}$ de sombra por baia. Foi realizado duas vezes por semana avaliação de ITU e frequência respiratória e quinzenalmente a avaliação de comportamento, com duração de 12 horas, com início as 6:00h e término às 18:00h, observou-se o comportamento alimentar, ruminação, descanso, outras atividades, social, cuidados corporais, lúdico e anormal. Observou-se um aumento significativo nos valores de ITU e FR a medida que se reduzia os níveis de sombreamento. Também foi observado uma diferença significativa no tempo de comportamentos de descanso e em outras atividades, e na frequência do consumo de água e comportamento lúdico, com aumento significativo no tempo de descanso e frequência de comportamento lúdico, e redução de outras atividades e ingestão de água em função do aumento dos níveis de sombreamento. Não se observou diferença significativa nos tempos de comportamento alimentar e de ruminação e nas frequências de micção, defecação, autolimpeza e comportamentos sociais e anormais. A utilização do sombreamento do tipo $80 \%$ porporciona um maior conforto aos animais, favorecendo do bem-estar e a qualidade de vida.

Palavras-chave: Ambiência. Bem-estar. Comportamento. Desempenho.

\section{Introduction}

The association between several climate conditions, such as air temperature, air relative humidity, wind, and solar radiation causes physiological changes that interfere with the behavior and productivity of animals. As the ambient temperature exceeds its critical temperature for calves, these animals experience heat stress, which causes behavioral and physiological alterations that affect production and reproduction (PERISSINOTTO et al., 2006).

Air humidity is another factor that may change the behavior and welfare of animals. According to Garcia (2006), high humidity percentages reduce sweating rate and obstruct water evaporation and transference of heat from the skin surface to the environment, resulting in the accumulation of body heat and discomfort. In an attempt to establish heat exchange with the environment, the animal adopts behavioral changes such as decreasing feed intake, increasing water intake and rest time, and displaying abnormal behaviors.

Facilities that provide thermal comfort to animals are thus required. Shading is highly important for controlling solar radiation, which is one of the main climatic factors directly affecting animals and interfering with other climatic elements (FERREIRA, 2005). Shade nets benefit the microclimate within a confinement area, where shaded pens may have lower temperatures and lower temperature-humidity indices, providing positive physiological responses like changes in respiratory frequency and behavioral responses in animals.

An increase in respiratory frequency occurs when animals feel heat stress resulting from their effort to increase evaporation thermolysis. Besides physiological responses, animals may display behavioral responses due to environmental variables.

The main behavioral factors affected by heat stress comprise increased water intake, decreased rumination, reduced daytime grazing and increased night grazing, longer idle periods, and increased number of abnormal stereotypic behaviors (MEYER et al., 2006; PIRES; CAMPOS, 2008).

Steers with behavioral disorders, e.g., sodomy, characterized by same-sex animals having intercourse with each other, may suffer injuries, lesions, and traumas, and consequently great energy losses, impaired performance, and even death (MALAFAIA et al., 2011).

This study evaluated the influence of artificial shading on environmental variables and on the physiological and behavioral responses of steers in intensive production systems. 


\section{Material and Methods}

The experiment was conducted in São Luís de Montes Belos - GO, Brazil (16³1'20' S and $50^{\circ} 22^{\prime} 48^{\prime}$ W), during 86 days, between July and October 2014, authorized by the Ethics Committee in the Animal Use (Comissão de Ética no Uso de Animais - CEUA) of the Federal University of Goiás (Universidade Federal de Goiás - UFG), under case no. 030/14. The climate of São Luís de Montes Belos is considered tropical, with an average temperature of $24.3{ }^{\circ} \mathrm{C}$ and average annual rainfall of $1566 \mathrm{~mm}$.

Forty-eight uncastrated male Nellore animals with an average initial weight of $310 \mathrm{~kg}$ (ranging from 306.75 to $314.33 \mathrm{~kg}$ ), at an average age of 20 months, originating from the same commercial herd, were used in the experiment. Animals were kept in the feedlot, in double stalls, in the NorthSouth direction, measuring four meters in width and six meters in length, totaling $24 \mathrm{~m}^{2}$. Twentyfour stalls were used in the total: six in the open air with $0 \%$ shading, six covered with a black shade net made of synthetic polypropylene fiber, 30\% light interception mesh; six with 50\% light interception; and six with $80 \%$ light interception, covering part of the area, with $6 \mathrm{~m}^{2}$ of shade per stall, distributed continuously.

The diet consisted of sorghum and corn silages, ground corn, soybean meal, soybean hulls, livestock urea, a mineral-vitamin mix, plus mineral supplementation ad libitum. The feed was supplied four times daily, at $06.00,10.00,13.00$, and 17.00 $\mathrm{h}$, with an average roughage:concentrate ratio of 40:60. The amount provided per animal/treatment was weighed every day, and orts were weighed before the first treatment of the day to calculate the total intake. Diets were formulated using the NRC software.

Ambient temperature and relative humidity of the air were measured twice weekly using thermohygrometers installed in a central stall in each treatment. These data were measured three times on the previously defined days, at $08.00,13.00$, and
$18.00 \mathrm{~h}$. Wind speed was also measured, in $\mathrm{km} / \mathrm{h}$, using a portable digital anemometer. Dry (DBT) and wet (WBT) bulb thermometer temperatures were collected using psychrometers to determine the temperature-humidity index (THI). The THI was calculated by the following formula: $\mathrm{THI}=\mathrm{DBT}+$ $0.36 \times \mathrm{WBT}+41.5$. Collections and determinations took place on the same days and at the same times when temperature and air relative humidity were measured.

Respiratory frequency (RF) was measured on days and at times established for the collection of environmental variables. Respiratory frequency was determined by counting movements of the flanks per minute, at $08.00 \mathrm{~h}, 13.00 \mathrm{~h}$, and 18.00 $\mathrm{h}$, prior to any movement that would alter this variable.

Evaluators were trained to identify the types of behavior under analysis, two days before evaluation, besides familiarizing the animals with their presence. On the day of behavior observation, the evaluators positioned themselves seven meters from the stalls so that their presence would not interfere with the animals' behavioral response.

Behavior was assessed fortnightly on the same day as that on which the environmental variables were recorded. Behavior was evaluated during 12 $\mathrm{h}$, from 06.00 to $18.00 \mathrm{~h}$, and comprised feeding, rumination, rest, and social activities such as body care and play and abnormal behaviors (Table 1).

The experimental design was completely randomized, with four treatments and six replications. A stall with two animals was the experimental unit; the trial comprised 24 stalls and 48 animals in total. Analysis of variance and Tukey's mean comparison test at 5\% significance were applied with environmental variables and behavioral responses of the animals. Correlations between environmental indices, such as THI and RF, were assessed. Statistical analyses were performed using R software version 2.15.2. (R CORE TEAM, 2015). 
Table 1. Ethogram with category and description of behavior reported in experimental confinement.

\begin{tabular}{ll}
\hline Behavior category & Description \\
\hline Feeding & Animal observed during feeding. \\
Rumination & $\begin{array}{l}\text { Process by which the already swallowed feed returns to the mouth for a further break of } \\
\text { the particles by chewing. }\end{array}$ \\
Rest & Animal lying on the ground, resting or sleeping; the animal may be doing some other \\
activity, such as rumination. \\
Social & Playing, rubbing, in dominance, or in contact. \\
Body care & Self-cleaning; cleaning others, urinating, defecating, and rubbing. \\
Abnormal & Stereotype-related; self-directed abnormal behavior; directed toward the environment or \\
Play & any other animal, such as sodomy, lignophagy, and geophagy. \\
Other activities & Play behavior. \\
\hline
\end{tabular}

\section{Results and Discussion}

Average air temperature was $31.8^{\circ} \mathrm{C}$ during the 86 days of confinement, with minimum temperature of $16.8^{\circ} \mathrm{C}$ and maximum temperature of $39.9{ }^{\circ} \mathrm{C}$.
Air relative humidity and wind speed averaged $43 \%$ and $4.8 \mathrm{~km} / \mathrm{h}$, respectively. The observed minimum and maximum THI values were 77 and 84 , respectively. In each treatment, the THI were determined, as shown in Table 2.

Table 2. Temperature-Humidity Index (THI), temperature, air relative humidity, and respiratory frequency (RF) in the stalls without shading and with shade nets of $30 \%, 50 \%$, and $80 \%$ light interception.

\begin{tabular}{|c|c|c|c|c|c|c|}
\hline \multirow{2}{*}{ Variable } & \multicolumn{4}{|c|}{ Shading level $(\%)^{1}$} & \multirow{2}{*}{$\mathrm{P}^{2}$} & \multirow{2}{*}{$\mathrm{CV}, \%^{3}$} \\
\hline & 0 & 30 & 50 & 80 & & \\
\hline THI & $80 \mathrm{~b}$ & $82 \mathrm{a}$ & $79 \mathrm{c}$ & $78 \mathrm{~d}$ & 0.035 & 6.07 \\
\hline Temperature & 32.2 & 32.5 & 31.7 & 30.8 & 0.097 & 9.13 \\
\hline Humidity & 42.7 & 42.5 & 43.2 & 43.6 & 0.387 & 8.93 \\
\hline $\mathrm{RF}$ (mov/min) & $28.67 \mathrm{ab}$ & $31.67 \mathrm{a}$ & $28.50 \mathrm{ab}$ & $26.17 \mathrm{~b}$ & 0.044 & 10.07 \\
\hline
\end{tabular}

${ }^{1}$ Variables followed by different letters in the same row differ at $5 \%$ significance level by Tukey's test; ${ }^{2}$ Probability rate of $\mathrm{F}$ test of analysis of variance; ${ }^{3}$ Coefficient of experimental variation.

The increase in THI caused an increase in the $\mathrm{RF}$ of the animals (Table 2). A positive correlation of 0.90 was found between THI and RF ( $>0.001)$, corroborating Azevedo et al. (2005), who recorded a correlation of 0.736 between RF and THI. This demonstrates that RF is a good indicator of heat stress, because an increase in THI levels means an increase in the need for heat dissipation by the animal, and RF is one of the main mechanisms for the transference of heat energy through the body's latent heat loss.
Average RF rates demonstrated that, in all treatments, RF remained within the normal limits for steers, since the environment was not stressful for the animals, with no need for heat dissipation. Hansen et al. (1999) reported that RF between 20 and $60 \mathrm{mov} / \mathrm{min}$ indicated a lack of heat stress; mild stress was revealed between 60 and $80 \mathrm{mov} / \mathrm{min}$; moderate stress occurred between 80 and $120 \mathrm{mov} /$ min; and when RF exceeded $120 \mathrm{mov} / \mathrm{min}$, cattle were under an excessive heat load. 
Besides the RF physiological response and the ambient THI, the behavioral responses of animals were assessed, comprising feeding behavior, rest, rumination and other activities (Table 3).

Table 3. Mean time ( $\mathrm{min}$ ) for feeding, rest, rumination, and other activities (OA) by animals in stalls without shading and with shade nets of $30 \%, 50 \%$, and $80 \%$ light interception.

\begin{tabular}{|c|c|c|c|c|c|c|c|}
\hline \multirow{2}{*}{$\begin{array}{l}\text { Behavior } \\
\text { (min) }\end{array}$} & \multicolumn{4}{|c|}{ Shade levels ${ }^{1}$} & \multirow{2}{*}{$\mathrm{p}^{2}$} & \multirow{2}{*}{$\mathrm{CV} \%{ }^{3}$} & \multirow{2}{*}{$\mathrm{SD}^{4}$} \\
\hline & 0 & 30 & 50 & 80 & & & \\
\hline Feeding & $174.83 a$ & $175.83 a$ & $176.17 \mathrm{a}$ & $161.17 \mathrm{a}$ & 0.664 & 14.12 & 24.30 \\
\hline Rest & $362.33 b$ & $394.33 \mathrm{ab}$ & $410.67 \mathrm{ab}$ & $432.67 \mathrm{a}$ & 0.048 & 11.46 & 45.86 \\
\hline Rumination & $135.00 \mathrm{a}$ & $159.17 \mathrm{a}$ & $136.33 \mathrm{a}$ & $143.83 \mathrm{a}$ & 0.109 & 12.51 & 17.95 \\
\hline $\mathrm{OA}$ & $182.84 \mathrm{a}$ & $149.84 \mathrm{ab}$ & $133.16 \mathrm{ab}$ & $126.16 \mathrm{~b}$ & 0.029 & 23.96 & 34.27 \\
\hline
\end{tabular}

${ }^{1}$ Variables followed by different letters in the same row differ at $5 \%$ significance level by Tukey's test; ${ }^{2}$ Probability rate of $\mathrm{F}$ test of the analysis of variance; ${ }^{3}$ Coefficient of experimental variation; ${ }^{4}$ Standard variation.

Feeding behavior, defined as the search for and consumption of food, is affected by characteristics and capabilities of animals, physical and chemical properties of the food, access to water, and disturbance factors such as environmental temperature, insects, and competitors. No difference $(p>0.05)$ was detected for the feeding behavior of animals in the stalls without shading and with shade nets of $30 \%, 50 \%$, and $80 \%$ light interception due to the mean room temperature of approximately $31.8{ }^{\circ} \mathrm{C}$, which, according to Ferreira (2005), does not interfere with the animal behavior. In fact, the lower and upper critical temperatures for zebu steers are approximately at 0 ${ }^{\circ} \mathrm{C}$ and $35^{\circ} \mathrm{C}$, respectively, with best performance between 10 and $27^{\circ} \mathrm{C}$.

Feed was supplied daily according to the established timetable, namely at 06.00, 10.00, 13.00, and $17.00 \mathrm{~h}$. Feeding behavior peaks were reported at these periods in the two treatments. According to Marques et al. (2007), this similarity may have stemmed from the two treatments having the same diet, which provided at the same time and in similar amounts. The feeding behavior of feedlot steers is changed when diets are provided at fixed and pre-determined times and the animal becomes accustomed to feeding in these periods.
The rumination behavior may be affected by the quality and quantity of feed, fiber content, and environmental conditions, among other factors. Similarly to the feeding behavior, no difference was detected among the treatments for rumination behavior. However, the highest rumination-behavior values were found in the treatment with the highest rate of feeding behaviors. It has also been reported that animals ruminate in the coolest hours of the day - at sunrise and sunset - mostly lying down or in the shade.

Marques et al. (2008) reported that young feedlot steers ruminated while lying down during $91 \%$ of the rumination period. Broom and Fraser (2010) reported that rumination peak occurs during the coolest periods of the day, especially after sunset, and that cattle lie down during rumination.

Silva et al. (2009) compared the behavior of cows with and without any shade and reported that the latter spent a longer time grazing (484 min) compared with the former (412 $\mathrm{min}$ ). However, the longer grazing period was not followed by an increase in rumination time $(338 \mathrm{~min}$ in the shade and $279 \mathrm{~min}$ in the sun) and did not indicate higher pasture intake. Animals in the shade are probably more efficient in grazing activities in periods with more-pleasant temperatures. 
Furthermore, animals in the shade have a longer rest period due to the favorable location. In fact, the rest time differed significantly according to the shading levels. Animals in stalls covered with $80 \%$ light interception netting had a longer rest period (432.67), and differed significantly from those kept in open-air stalls without any shade (362.33), but did not differ from the animals in stalls with $30 \%$ (394.33) and 50\% (410.67) light interception netting.

Marques et al. (2007) reported a longer rest time by animals in shaded environments (176.5 min) compared with animals reared in the open air and exposed to solar radiation (146.2 min), due to the better environment and thermal comfort for the animals with more access to shade. In fact, a shaded area retains a greater amount of humidity and facilitates heat exchange between the animal and the environment.

Animals often rest by lying down, in lateral recumbency, since they do not rest satisfactorily while standing. The animal may thus use its rest time for other activities such as rumination.

To compensate for the lower rest time, the animals kept in the open air without any shade spent more time on other activities and differed $(\mathrm{p}<0.05)$ from animals kept in stalls with $80 \%$ light interception netting, but did not differ from the animals in stalls covered with $30 \%$ and 50\% light interception netting (Table 3).

Frequency of water consumption differed $(p<0.05)$ among treatments (Table 4). Animals in stalls without any shading or with $30 \%$ light interception netting drank more water when compared with animals in stalls covered with $30 \%$ and $50 \%$ light interception netting, due to exposure to solar radiation during the entire day or due to stalls having little light interception. Meyer et al. (2006) reported that water intake increases as the ambient temperature and light interception are increased, since animals use water to control the harmful effects of heat and maintain homeostasis (COIMBRA et al., 2007).

Table 4. Mean frequency of water intake, urination, defecation, abnormal behavior, cleaning others, play behavior, social behavior, and self-cleaning of animals in the stalls without shading and with shade nets of $30 \%, 50 \%$, and $80 \%$ light interception.

\begin{tabular}{lccccccc}
\hline \multirow{2}{*}{$\begin{array}{l}\text { Frequency of } \\
\text { behavior }\end{array}$} & \multicolumn{9}{c}{ Shade levels ${ }^{1}$} & \multirow{2}{*}{$\mathrm{p}^{2}$} & CV\% & SD $^{4}$ \\
\cline { 2 - 5 } & 0 & 30 & 50 & 80 & & & \\
\hline Water & $15.50 \mathrm{a}$ & $15.33 \mathrm{a}$ & $12.17 \mathrm{ab}$ & $8.17 \mathrm{~b}$ & 0.028 & 34.27 & 4.38 \\
Urination & $3.50 \mathrm{a}$ & $3.67 \mathrm{a}$ & $4.83 \mathrm{a}$ & $3.00 \mathrm{a}$ & 0.110 & 33.33 & 1.25 \\
Defecation & $4.50 \mathrm{a}$ & $4.83 \mathrm{a}$ & $4.50 \mathrm{a}$ & $4.50 \mathrm{a}$ & 0.946 & 25.55 & 1.17 \\
Abnormal & $10.33 \mathrm{a}$ & $8.67 \mathrm{a}$ & $7.17 \mathrm{a}$ & $6.67 \mathrm{a}$ & 0.083 & 59.20 & 4.86 \\
Cleaning others & $6.17 \mathrm{a}$ & $8.33 \mathrm{a}$ & $9.33 \mathrm{a}$ & $12.67 \mathrm{a}$ & 0.181 & 54.22 & 4.95 \\
Play & $5.83 \mathrm{a}$ & $8.00 \mathrm{ab}$ & $9.17 \mathrm{ab}$ & $12.00 \mathrm{a}$ & 0.049 & 40.91 & 3.58 \\
Social & $23.00 \mathrm{a}$ & $18.77 \mathrm{a}$ & $23.33 \mathrm{a}$ & $26.17 \mathrm{a}$ & 0.154 & 25.50 & 5.82 \\
Self-cleaning & $15.50 \mathrm{a}$ & $19.50 \mathrm{a}$ & $18.33 \mathrm{a}$ & $16.67 \mathrm{a}$ & 0.706 & 36.11 & 6.32 \\
\hline
\end{tabular}

${ }^{1}$ Variables followed by different letters in the same row differ at $5 \%$ significance level by Tukey's test; ${ }^{2}$ Probability rate of $\mathrm{F}$ test of the analysis of variance; ${ }^{3}$ Coefficient of experimental variation; ${ }^{4}$ Standard variation.

No significant $(\mathrm{p}>0.05)$ were found between frequency of urination, defecation, abnormal behavior, cleaning others, self-cleaning, and social behaviors among the treatments. 
According to Broom and Fraser (2010), steers under normal conditions and within a 24-h cycle urinate approximately nine times and defecate between 12 and 18 times, even though the number of times and amounts eliminated vary according to the type of feed provided, environmental conditions, and animal characteristics. Self-cleaning is the act of an animal touching two parts of its body, such as licking and scratching, and also when it touches the surrounding environment, such as poles, trees, stones, and hedges. Cleaning others is defined as two or more animals licking one another or rubbing their body onto that of another animal. Social behavior is any contact with other animals.

Cases of abnormal behavior were detected in all treatments due to stress from changes in the production system; for instance, the previously extensive grazing being transformed into feedlot. This fact limited the space for the development of normal behavior such as search for food, locomotion, social interactions, and others.

Lignophagy in animals consists of chewing and eating pieces of corral hedge poles or eucalyptus poles used for shading, while geophagy is soileating. According to Broom and Fraser (2010) lignophagy may cause several intestine obstructions or lesions in the mouth of animals and may be due to lack of roughage, or stress. Geophagy may be due to dietary deficiencies of minerals, especially iron and phosphorus, and may occur due to strict confinement and lack of exercise. It may cause serious problems to the abomasum of cattle.

According to Malafaia et al. (2011) sodomy is a behavioral disorder when an animal attempts to have intercourse with another, normally bigger and stronger animal of the same sex. The process may cause wounds and lesions on the carcass. Sodomy may be related to lack of well-being rather than sexual desire. The main issue in sodomy is that the dominating animals may be subjected to lesions on their hooves and hind parts, besides harming the other animals. These lesions may also interfere negatively with feed intake, decrease weight gain, and cause losses in animal performance.

Sodomy, followed by geophagy, biting hedges, and lignophagy, with mean frequencies of $61.5 \%$, $17.7 \%, 10.5 \%$, and $10.3 \%$ respectively, are among the reported types of abnormal behavior.

Play behavior consists of recreational activities among the animals, characterized by jumps, running, and other demonstrations of well-being. Such behavior has no specific aim and is more perceived in young than in older animals.

A significant difference $(\mathrm{p}<0.05)$ was detected between the frequency of play behavior for animals in stalls with $80 \%$ light interception netting when compared with those under direct sunlight, and no differences were found between animals in stalls covered with $30 \%$ and $50 \%$ light interception netting. This result is due to the more-favorable environment for animals in the shade, particularly under $80 \%$ light interception shade netting.

\section{Conclusions}

The use of shading with $80 \%$ light interception provided comfort, allowing greater welfare and quality of life to animals.

\section{References}

AZEVEDO, M.; PIRES, M. F.; SATUMINO, H. M.; LANA, A. M. Q.; SAMPAIO, I. B. M.; MONTEIRO, J. B. N.; MORATO, L. E. Estimativa de níveis críticos superiores do índice de temperatura e umidade para vacas leiteiras 1/2, 3/4 e 7/8 Holandês-Zebu em lactação. Revista Brasileira de Zootecnia, Viçosa, MG, v. 34, n. 6, p. 2000-2008, 2005.

BROOM, D. M.; FRASER, A. F. Comportamento e bemestar de animais domésticos. 4. ed. Barueri: Manole, 2010. $421 \mathrm{p}$.

COIMBRA, P. A. D.; MACHADO, T. M. P.; MACHADO FILHO, L. P.; HOTZEL, M.; NUNES, P.; LIPIARSKI, V. A influência da localização do bebedouro e da sombra no comportamento de bovinos em pastoreio. Revista Brasileira de Agroecologia, Porto Alegre, v. 2, n. 2, p. 825-829, 2007. 
FERREIRA, R. A. Maior produção com melhor ambiente para aves, suínos e bovinos. Viçosa, MG: Aprenda Fácil, 2005. $371 \mathrm{p}$.

GARCIA, A. R. Influência de fatores ambientais sobre as características reprodutivas de búfalos do rio (Bubalusbubalis). Revista de Ciências Agrárias, Belém, n. 45, p.1-13, 2006. Suplemento.

HANSEN, P. J.; ARECHIGA, C. F. Strategies for managing reproduction in the heat-stressed dairy cow. Journal of Animal Science, v. 77, p. 36-50, 1999. Supplement 2.

MALAFAIA, P.; BARBOSA, J. D.; TOKARNIA, C. H.; OLIVEIRA, C. M. C. Distúrbios comportamentais em ruminantes não associados a doenças: origem, significado e importância. Pesquisa Veterinária Brasileira, Seropédica, v. 31, n. 9, p. 781-790, 2011.

MARCHETO, F. G. NAAS, I. A.; SALGADO, D’A.; SOUZA, S. R. L. Efeito das temperaturas de bulbo seco e de globo negro e do índice de temperatura e umidade, em vacas em produção alojadas em sistema free-stall. Brazilian Journal of Veterinary Research and Animal Science, São Paulo, v. 39, n. 6, p. 320-323, 2002.

MARQUES, J. A.; CALDAS NETO, S. F.; GROFF, A. M.; SIMONELLI, S. M.; CORASA, J.; ROMERO, L.; ZAWADSKI, F.; ARAÚJO, P. F. Comportamento de bovinos mestiços em confinamento com e sem acesso a sombra durante o período de verão. Campo Digital, Campo Mourão, v. 1, n. 1, p. 54-59, 2006.

MARQUES, J. A.; ITO, R. H.; ZAWADZKI, F.; MAGGIONI, D.; BEZERRA, G. A.; PEDROSO, P. H.; PRADO, I. N. Comportamento ingestivo de tourinhos confinados com ou sem acesso à sombra. Campo Digital, Campo Mourão, v. 2, n. 1, p. 43-49, jan./jun. 2007.
MARQUES, J. A.; PINTO, A. P.; ABRAHÃO, J. J. S.; NASCIMENTO, W. G. Intervalo de tempo entre observações para avaliação do comportamento ingestivo de tourinhos em confinamento. Semina: Ciências Agrárias, Londrina, v. 29, n. 4, p. 955-960, 2008.

MEYER, U.; STAHL, W.; FLACHOWSKY, G. Investigation son the water in take of growing bulls. Livestock Production Science, Washington, v.103, n. 1, p. 186-191, 2006.

PERISSINOTTO, M.; MOURA, D. J.; MATARAZZO, S. V.; SILVA, I. J. O.; LIMA, K. A. O. Efeito da utilização de sistemas de climatização nos parâmetros fisiológicos do gado leiteiro. Engenharia Agrícola, Jaboticabal, v. 36, n. 3, p. 663-671, 2006.

PIRES, M. F. A.; CAMPOS, A. T. Conforto animal para maior produção de leite. Viçosa, MG: CPT, 2008. 254 p.

R CORE TEAM - R: a language and environment for statistical computing. R Foundation for Statistical Computing, Vienna, Austria: the R Foundation for Statistical Computing, 2015. Available at: <http:// www.R-project.org/>. Accessed at: 03 october 2015.

SILVA, E. C. L.; MODESTO, E. C.; AZEVEDO, M.; FERREIRA, M. A.; DUBEUX JÚNIOR, J. C. B.; SCHULER, A. R. P. Efeitos da disponibilidade de sombra sobre o desempenho, atividades comportamentais e parâmetros fisiológicos de vacas da raça Pitangueiras. Acta Scientiarum. Animal Sciences, Maringá, v. 31, n. 3, p. 295-302, 2009. 